\title{
Antioxidants attenuate early up regulation of retinal vascular endothelial growth factor in streptozotocin-diabetic rats
}

\author{
I. G. Obrosova ${ }^{1}$, A. G. Minchenko ${ }^{2}$, V.Marinescu ${ }^{1}$, L. Fathallah ${ }^{1}$, A. Kennedy ${ }^{3}$, C.M.Stockert ${ }^{1}$, R.N.Frank ${ }^{3}$, \\ M.J.Stevens ${ }^{1,4}$ \\ ${ }^{1}$ Division of Endocrinology and Metabolism, Department of Internal Medicine, University of Michigan Medical Centre, \\ Ann Arbor, Michigan, USA \\ ${ }^{2}$ Department of Anesthesiology, Thomas Jefferson University, Philadelphia, Pennsylvania, USA \\ ${ }^{3}$ Department of Ophthalmology, Kresge Eye Institute, Wayne State University School of Medicine, Detroit, Michigan, USA \\ ${ }^{4}$ Veterans Administration Medical Centers, Ann Arbor, Michigan, USA
}

\section{Abstract}

Aims/hypothesis. A strong positive correlation has been found between lipid peroxidation product and vascular endothelial growth factor concentrations in the vitreous of patients with proliferative diabetic retinopathy. To establish a causal relation between diabetes-associated enhanced oxidative stress and vascular endothelial growth factor production, we evaluated two antioxidants, DL- $\alpha$-lipoic acid and taurine, on retinal vascular endothelial growth factor protein and mRNA expression and on parameters of oxidative stress in streptozotocin-diabetic rats.

Methods. Our experiments were on control rats and streptozotocin-diabetic rats with a 6-week duration of diabetes, treated with or without DL- $\alpha$-lipoic acid $\left(100 \mathrm{mg} \cdot \mathrm{kg}^{-1} \cdot \mathrm{d}^{-1}, \mathrm{i} . \mathrm{p}.\right)$ or taurine $(1 \%$ in the diet $)$ starting from induction of diabetes. Vascular endothelial growth factor protein in retinal homogenates was assessed by sandwich ELISA with an affinity-purified polyclonal antibody and vascular endothelial growth factor mRNA by ribonuclease protection assay. Retinal lipid peroxidation products i.e. malondialdehyde plus 4-hydroxyalkenals were quantified with N-methyl-2-phenylindole. Retinal reduced and oxidized glutathione, ascorbate, dehydroascorbate, and sorbitol pathway intermediates were measured spectrofluorometrically, and taurine by reverse-phase HPLC.
Results. Vascular endothelial growth factor protein concentration (means \pm SD) was increased in diabetic rats compared with control rats $(33 \pm 7 \mathrm{vs} 19 \pm 5 \mathrm{pg} / \mathrm{mg}$ total protein, $p<0.01)$ This increase was attenuated by taurine $(26 \pm 8, p<0.05)$ and prevented by DL$\alpha$-lipoic acid $(21 \pm 4, p<0.01)$. Vascular endothelial growth factor mRNA abundance was reduced by 1.4fold in diabetic rats compared with control rats and this decrease was attenuated but not completely prevented by both antioxidants. Malondialdehyde plus 4-hydroxyalkenal concentration was increased in diabetic rats compared with control rats, and both antioxidants arrested accumulation of lipid peroxidation products. Taurine, reduced glutathione, oxidized glutathione, ascorbate, dehydroascorbate and sorbitol pathway intermediate concentrations as well as oxidized glutathione/reduced glutathione and dehydroascorbate/ascorbate ratios were similar in control and diabetic rats treated with or without taurine.

Conclusion/interpretation. Oxidative stress is directly involved in up regulation of vascular endothelial growth factor protein in the retina during early diabetes. [Diabetologia (2001) 44: 1102-1110]

Keywords Ascorbate, lipid peroxidation, DL- $\alpha$-lipoic acid, oxidative stress, rat, retina, sorbitol pathway of glucose metabolism, streptozotocin-diabetes, taurine, vascular endothelial growth factor.
Received: 29 December 2001 and in revised form: 21 May 2001

Corresponding author: Dr. I. G. Obrosova, Division of Endocrinology and Metabolsim, Department of Internal Medicine, University of Michigan Medical Centre, 1150 West Medical Center Drive, MSRB II, Rm 5570, Ann Arbor, Michigan 48109-0354, e-mail: iobrosso@umich.edu
Abbreviations: AA, Free ascorbate; AR, aldose reductase; DHAA, dehydroascorbate; ROS, reactive oxygen species; GSH, reduced glutathione; GSSG, oxidized glutathione; MDA, malondialdehyde; 4-HA, 4-hydroxyalkenals; VEGF, vascular endothelial growth factor 
The Diabetes Control and Complications Trial [1] and the United Kingdom Prospective Diabetes Study [2] indicate a strong consistent relation between hyperglycaemia and the incidence and progression of diabetic complications in patients with Type I (insulin-dependent) and Type II (non-insulin-dependent) diabetes mellitus. Chronic hyperglycaemia leads to sorbitol pathway hyperactivity, non-enzymatic glycation/glycoxidation and protein kinase $\mathrm{C}$ activation, all of which have been implicated in the pathogenesis of diabetic complications [3-5] including retinopathy $[3,6-8]$.

One of the most dangerous consequences of diabetes-associated "glucose toxicity" is oxidative stress resulting from increased production of reactive oxygen species (ROS) and insufficient up regulation [9] and often down regulation $[10,11]$ of the antioxidative defence mechanisms. Reactive oxygen species are involved in decreased retinal blood flow [12], increased vascular permeability and disruption of blood-retinal barrier [13,14], and the appearance of acellular capillaries $[15,16]$ from apoptotic loss of retinal capillary cells [16]. Recent findings suggest that premature apoptosis of pericytes and endothelial cells is induced by poly(ADP-ribosyl)ation $[17,18]$ which, in turn, is caused by hydroxyl radicals [19] and peroxynitrite [20] formed in the reaction of superoxide anion radicals with nitric oxide. Furthermore, in vitro studies $[14,21-23]$ implicate oxidative stress in the excessive production of vascular endothelial growth factor (VEGF) which is associated with increased vascular permeability and disruption of blood-retinal barrier $[7,13,24]$ in background diabetic retinopathy as well as neovascularization $[25,26]$ in proliferative diabetic retinopathy. A strong positive correlation has been found between lipid peroxidation product and VEGF concentrations in the vitreous of patients with proliferative diabetic retinopathy [27].

VEGF formation is controlled by oxygen supply [28, 29], $\mathrm{pH}$ [30], and glucose concentration [31]. Retinal VEGF immunoreactivity in the galactose model of diabetic retinopathy is suppressed by inhibitors of aldose reductase and non-enzymatic glycation [6] i. e. two major mechanisms contributing to ROS generation $[11,32,33]$. To determine a causal relation between diabetes-induced oxidative stress and VEGF formation, we evaluated two antioxidants, DL- $\alpha$-lipoic acid and taurine, on variables of lipid peroxidation, antioxidative defence and VEGF protein and mRNA concentrations in the retinae of streptozotocin-diabetic rats with 6-week duration of diabetes. Enhanced oxidative stress and VEGF up regulation have been documented in the rat and mouse models early in the course of diabetes [34-36]. Taurine and DL- $\alpha$-lipoic acid penetrate through the blood-retinal barrier [34, 37, 38].

\section{Materials and methods}

The experiments were done in accordance with regulations specified by The Guiding Principles in the Care and Use of Animals (DHEW Publication, NIH 80-23) and the University of Michigan Protocol for Animal Studies.

Animals. Barrier-sustained, Caesarean-delivered male Wistar rats (Charles River, Wilmington, Mass., USA), body weight 250 to $300 \mathrm{~g}$, were fed a standard rat chow diet (ICN Biomedicals, Cleveland, Ohio, USA) and had ad libitum access to water. Diabetes was induced by a single intraperitoneal injection of streptozotocin $(55 \mathrm{mg} / \mathrm{kg}$ body weight, i.p.). Blood samples for measurements of glucose were taken from the tail vein about $48 \mathrm{~h}$ after streptozotocin injection and the day before the rats were killed. Rats with blood glucose of $13.9 \mathrm{mmol} / \mathrm{l}$ or more were considered diabetic. The 6-week diabetic rats were treated with or without DL- $\alpha$-lipoic acid $\left(100 \mathrm{mg} \cdot \mathrm{kg}^{-1} \cdot \mathrm{d}^{-1}\right.$, i.p.) or taurine ( $1 \%$ in the diet). Both treatments were started after diabetes was confirmed i. e. about $48 \mathrm{~h}$ after streptozotocin injection.

Reagents. Unless otherwise stated, all chemicals were of reagent-grade quality (Sigma Chemical, St. Louis, Mo., USA). Methanol (HPLC grade), perchloric acid, hydrochloric acid, and sodium hydroxide were purchased from Fisher Scientific, Pittsburgh, Pa., USA. Ethyl alcohol (200 proof dehydrated alcohol, U.S.P. punctilious) was purchased from McCormick Distilling, Weston, Mo., USA. $\beta$-D-Glucose, sorbitol, N.F., and D-fructose, U.S.P. were purchased from Pfanstiehl Laboratories, Waukegan, Ill., USA. [ $\left.\alpha^{32} \mathrm{P}\right]-\mathrm{UTP}(800 \mathrm{Cu} / \mathrm{mmol})$ was purchased from NEN Life Science Products, Arlington, Ill., USA. Kits for measurements of malondialdehyde (MDA) and 4-hydroxyalkenals (4-HA) were purchased from Oxis International, Portland, Ore., USA, kits for VEGF measurements and rat VEGF protein from R and D Systems, Minneapolis, Minn., USA, and bicinchoninic acid protein assay kits from Pierce, Rockford, Ill., USA.

Experimental procedure. Rats were sedated with carbon dioxide and immediately killed by cervical dislocation. Both retinae were rapidly dissected and frozen in liquid nitrogen. In experiment one, three retinae from three animals were pooled for each VEGF protein measurement. The variables MDA plus 4-HA, GSH, GSSG, DHAA, AA, taurine, glucose, sorbitol and fructose were measured in individual retinae. Taurine, GSH, GSSG, DHAA and AA concentrations were measured in control and diabetic rats treated with or without taurine. We have reported the effects of DL- $\alpha$-lipoic acid on retinal oxidative stress and sorbitol pathway activity previously [34, 39]. In experiment two, individual retinae were used for measurements of VEGF mRNA.

VEGF Enzyme-Linked Immunosorbent Assay (ELISA). Material from three retinae was homogenized in $50 \mathrm{mmol} / \mathrm{l}$ Trisbuffer ( $\mathrm{pH} \mathrm{8.0)}$ and centrifuged at $10000 \mathrm{~g}$ for $10 \mathrm{~min}$ (Sorvall MC $12 \mathrm{~V}$ ). 50 ( $\mu \mathrm{l}$-aliquots of the supernatant were used for VEGF measurements. VEGF was assayed by a sandwich ELISA with an affinity-purified polyclonal antibody specific for mouse VEGF according to the manufacturer's instructions. Good linearities $\left(r_{\text {mouse }}=0.996\right.$ and $\left.r_{\text {rat }}=0.986\right)$ were obtained with this antibody and mouse and rat VEGF standards in the range of 5 to $500 \mathrm{pg} / \mathrm{ml}$ (Fig. 1) as well as rat VEGF standards in the range of 15 to $500 \mathrm{pg} / \mathrm{ml}$ added to rat retinal homogenates $(r=0.964)$. The average recovery was $81 \%$. Intra-assay and inter-assay coefficients of variability were $3.2 \pm 2.0$ and 


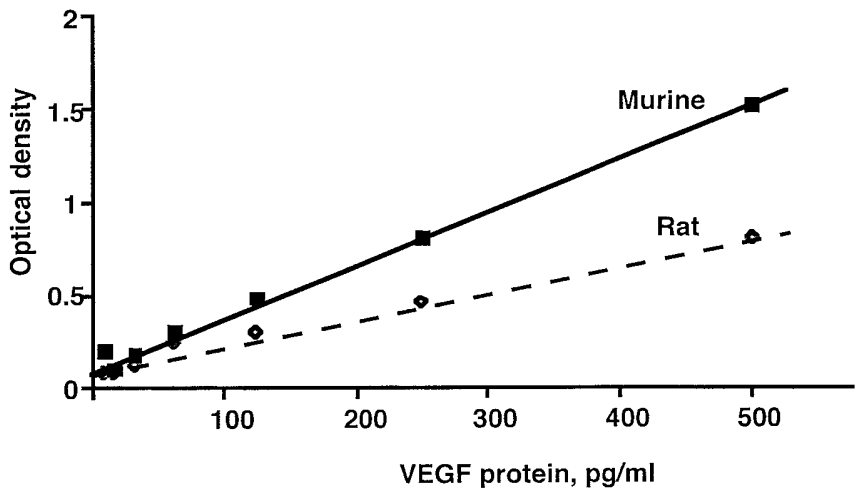

Fig. 1. Representative standard curves obtained in the sandwich ELISA of murine and rat VEGF proteins with an affinity-purified polyclonal antibody specific for mouse VEGF

$6.4 \pm 5.5$, respectively. VEGF concentrations were assayed in triplicate and normalized to total protein. For total protein measurements, $50 \mu \mathrm{l}$-aliquots of the retinal homogenate were mixed with $0.5 \mathrm{ml} 0.1 \mathrm{~N} \mathrm{NaOH}$, sonicated and left overnight for complete solubilization. Proteins were quantified according to the manufacturer's instructions.

$R N A$ preparation. Total RNA was isolated using the acid guanidium-phenol-chloroform extraction method [40] with minor modification [41]. Retinae were homogenized in $0.4 \mathrm{ml}$ of guanidine isothiocyanate solution containing $4 \mathrm{~mol} / \mathrm{l}$ guanidine isothiocyanate, $50 \mathrm{mmol} / \mathrm{l}$ tris- $\mathrm{HCl}, 25 \mathrm{mmol} / \mathrm{l}$ EDTA and $0.1 \mathrm{~mol} / \mathrm{l} \beta$-mercaptoethanol. Sequentially, $0.04 \mathrm{ml}$ of $2 \mathrm{~mol} / 1$ sodium acetate ( $\mathrm{pH} 4.0), 0.4 \mathrm{ml}$ of water saturated phenol and $0.08 \mathrm{ml}$ of chloroform-isoamyl alcohol mixture (49:1) were added to homogenate, with thorough mixing after each reagent was added. RNA was precipitated with equal volume of 2 -propanol. RNA pellets were washed with $75 \%$ ethanol and dissolved in nuclease-free water.

Quantification of VEGF mRNA concentrations by ribonuclease protection assay. The plasmid for synthesis of the rat VEGF probe was created by synthesis of a cDNA using rat heart total RNA and oligo(dT) followed by cloning. VEGF cDNA was amplified using forward primer (5' ccggatCCTCCGAAACCATGAACTTTCTGC-3') and reverse primer (5'-ccggaatTCTGGATTAAGGACTGTTCTGTC-3') corresponding to nucleotide sequences 46-69 and 773-751 of the human VEGF cDNA, respectively ([42] GenBank accession number M32977). PCR fragments of VEGF cDNA were digested with BamHI and EcoRI and cloned into plasmid pBluescript II KS + for ribonuclease protection assays. The plasmid containing VEGF cDNA was digested with $X b a$ I to make a 735-base radiolabelled antisense probe. The plasmid for synthesis of the rat $18 \mathrm{~S}$ probe was created by synthesis of a cDNA using rat lung total RNA using forward primer (5'-AGATCAAAACCAACCCGG-3') and reverse primer (5'ATTCCTAGCTGCGGTATC-3'). These oligonucleotides correspond to nucleotide sequences 236-253 and 876-859 of rat $18 \mathrm{~S}$ rRNA, respectively ([43] GenBank accession number M11188). This fragment of cDNA for $18 \mathrm{~S}$ rRNA was digested with Pst I and $X b a I$ and cloned into plasmid pBluescript II $\mathrm{SK}+$ for ribonuclease protection assays. This plasmid was digested with $X b a \mathrm{I}$ and used as a template for in vitro transcription of a 435-base radiolabelled antisense probe (predicted to protect a 372-base fragment) using T7 RNA-polymerase and $\left[\alpha{ }^{32} \mathrm{P}\right]-\mathrm{UTP}$. The rat18S ribosomal RNA antisense probe was used to normalize VEGF gene expression to total RNA. All constructs were verified by sequencing and were found to be $100 \%$ identical to the published sequences.

Synthesis of radiolabelled antisense probes for ribonuclease protection assay was done according to the Boehringer Mannheim protocol using T7 or T3 RNA polymerase and $\left[\alpha^{32} \mathrm{P}\right]$-UTP. For ribonuclease protection assays, water solutions of total RNA were dried under vacuum and dissolved in $25 \mu \mathrm{l}$ of $80 \%$ formamide hybridization buffer containing labelled probes. Samples were preincubated for $5 \mathrm{~min}$ at $85^{\circ} \mathrm{C}$ and then incubated for $16 \mathrm{~h}$ at $45^{\circ} \mathrm{C}$ [29]. The extracted, protected probe fragments were run on a $6 \%$ polyacrylamide sequencing gel in 1. Tris-borate-EDTA buffer for $2 \mathrm{~h}$ at $50 \mathrm{~mA}$. The gel was then dried and exposed to X-ray film at $-70^{\circ} \mathrm{C}$. Expression of mRNA was quantified using a PhosphorImager (Molecular Dynamics, Sunnyvale, Calif., USA). The intensity of each VEGF mRNA band was normalized for $18 \mathrm{~S}$ ribosomal RNA level. No differences were detected between the various VEGF mRNA transcripts in the response to the different experimental conditions.

Sorbitol pathway intermediates. Retinae were homogenized in $1.5 \mathrm{ml} 0.1 \mathrm{~mol} / \mathrm{l}$ sodium-phosphate buffer, $\mathrm{pH}$ 6.5. Then a $0.1 \mathrm{ml}$-volume of $0.3 \mathrm{~mol} / \mathrm{l}$ zinc sulfate, followed by an equivalent of barium hydroxide, was added to $0.3 \mathrm{ml}$ of the homogenate for protein precipitation. The samples were centrifuged at $4000 \mathrm{~g}$ for $10 \mathrm{~min}$ (Sorvall MC $12 \mathrm{~V}$ ) and aliquots of the supernatant were taken for spectrofluorometric measurements of glucose, sorbitol and fructose by enzymatic procedures [44].

Malondialdehyde plus 4-hydroxyalkenals, GSH and GSSG. $0.6 \mathrm{ml}$ of the retinal homogenates described above were used for measurements of MDA plus 4-HA, GSH and GSSG [34]. GSH and GSSG were assayed in perchloric acid extracts. The concentrations were normalized to total protein.

$D H A A$ and $A A .0 .2 \mathrm{ml}$ of the homogenates described above were mixed with $0.2 \mathrm{ml}$ of ice-cold $10 \%$ metaphosphoric acid and centrifuged at $4000 \mathrm{~g}$ for $10 \mathrm{~min}$. For measurements of DHAA, $0.1 \mathrm{ml}$ of the supernatant was mixed with $0.9 \mathrm{ml}$ $2 \mathrm{~mol} / \mathrm{l} \mathrm{Na}$-acetate buffer, $\mathrm{pH}$ 6.2. The reaction is started by adding $0.02 \mathrm{ml} 92.5 \mathrm{mmol} / \mathrm{l} \mathrm{O}$-phenylenediamine and is completed after $30 \mathrm{~min}$. The initial and final readings are taken at $\lambda$ excitation: $350 \mathrm{~nm}$, emission: $430 \mathrm{~nm}$. For measurements of total AA, $0.1 \mathrm{ml}$ of the supernatant was mixed with $0.9 \mathrm{ml}$ $2 \mathrm{~mol} / \mathrm{l} \mathrm{Na}$-acetate buffer, $\mathrm{pH} 6.2$ and $10 \mathrm{U}$ of ascorbate oxidase to convert free AA to DHAA. The reaction is completed in $30 \mathrm{~min}$. Then DHAA was quantified as described above. AA concentrations were calculated as the difference between total AA and DHAA.

Taurine. Retinal taurine concentrations were measured by reverse-phase HPLC (apparatus: Waters 501, pumps: Waters 717; autosampler: Waters 470; column: Waters $3.9 \cdot 150 \mathrm{~mm}$ Nova-Pack C18; scanning fluorescence detector: $\lambda$ excitation: $360 \mathrm{~nm}$; $\lambda$ emission: $455 \mathrm{~nm}$; and Waters Millenium Software; Waters, Milford, Mass., USA) after precolumn derivatization with O-phthaldialdehyde reagent [45] (10 mg O-phthaldialdehyde dissolved in $0.2 \mathrm{ml}$ absolute ethanol were mixed with 10 $\mu \mathrm{l}$ mercaptoethanol and $5 \mathrm{ml} 0.5 \mathrm{~mol} / \mathrm{l}$ borate buffer, $\mathrm{pH} 10.3$ ). In brief, $0.1 \mathrm{ml}$ of retinal homogenate described above and taurine standards in the range of $1-10 \cdot 10^{-9} \mathrm{~mol} / \mathrm{l}$ were extracted with $1 \mathrm{ml}$ of $12 \%$ perchloric acid and centrifuged at $4000 \mathrm{~g}$ for $10 \mathrm{~min}$. The supernatants were purified on washed dual-bed ion-exchange columns (2.5 cm AG 1-X8 100-200 mesh; BioRad Lab., Hercules, Calif., USA; in the chloride form over $2.5 \mathrm{~cm}$ AG 50W-X8 200/400 mesh (Bio-Rad) in the hydrogen 
Table 1. Final body weight and blood glucose concentrations in control and diabetic rats treated with or without DL- $\alpha$-lipoic acid or taurine $(n=18-27)$

\begin{tabular}{|c|c|c|c|c|}
\hline & Control & Diabetic & $\begin{array}{l}\text { Diabetic } \\
+\mathrm{T}\end{array}$ & $\begin{array}{l}\text { Diabetic } \\
+ \text { LA }\end{array}$ \\
\hline $\begin{array}{l}\text { Experiment } 1 \\
\text { Final body weight }(\mathrm{g}) \\
\text { Blood glucose concentration }(\mathrm{mmol} / \mathrm{l})\end{array}$ & $\begin{array}{c}494 \pm 45 \\
3.5 \pm 0.53\end{array}$ & $\begin{array}{c}231 \pm 26^{\mathrm{a}} \\
25.2 \pm 4.5^{\mathrm{a}}\end{array}$ & $\begin{array}{c}243 \pm 32^{\mathrm{a}} \\
24.9 \pm 4.5^{\mathrm{a}}\end{array}$ & $\begin{aligned} 229 & \pm 27^{\mathrm{a}} \\
27.1 & \pm 3.7^{\mathrm{a}}\end{aligned}$ \\
\hline $\begin{array}{l}\text { Experiment } 2 \\
\text { Final body weight }(\mathrm{g}) \\
\text { Blood glucose concentration }(\mathrm{mmol} / \mathrm{l})\end{array}$ & $\begin{array}{c}437 \pm 38 \\
3.94 \pm 0.24\end{array}$ & $\begin{array}{c}283 \pm 36^{\mathrm{a}} \\
22.0 \pm 4.3^{\mathrm{a}}\end{array}$ & $\begin{array}{c}298 \pm 44^{\mathrm{a}} \\
20.9 \pm 1.7^{\mathrm{a}}\end{array}$ & $\begin{array}{c}286 \pm 38^{\mathrm{a}} \\
21.3 \pm 2.5^{\mathrm{a}}\end{array}$ \\
\hline
\end{tabular}

a Significantly different from controls $(p<0.01)$

$\mathrm{T}$, taurine; LA, DL- $\alpha$-lipoic acid

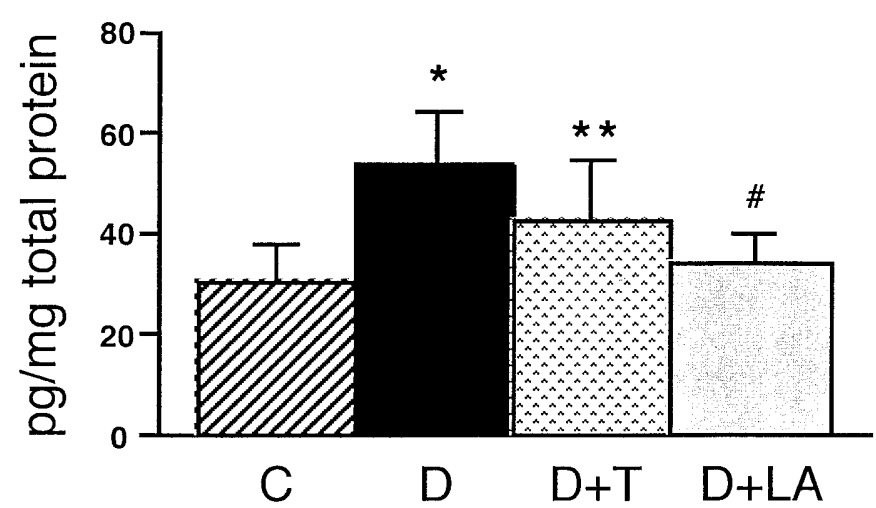

Fig. 2. Retinal VEGF concentrations in control and diabetic rats treated with or without taurine or DL- $\alpha$-lipoic acid (mean $\pm \mathrm{SD}, n=6-8$ ). C, control rats; $\mathrm{D}$, untreated diabetic rats; $\mathrm{D}+\mathrm{T}$, diabetic group treated with taurine; $\mathrm{D}+\mathrm{LA}$, diabetic group treated with DL- $\alpha$-lipoic acid. *significantly different vs controls $(p<0.01)$; ** * significantly different vs untreated diabetic group ( $p<0.05$ and $<0.01$, respectively)

form) by elution with $2 \mathrm{ml} \mathrm{H}_{2} \mathrm{O}$. The eluents were washed twice with $\mathrm{H}_{2} \mathrm{O}$-saturated ether and lyophilized. Samples and standards were dissolved in $100 \mu \mathrm{l} \mathrm{H}_{2} \mathrm{O}$ before HPLC analysis. Isocratic elution was carried out at a flow rate of $2 \mathrm{ml} / \mathrm{min}$ using $43 \%$ solvent $\mathrm{A}$ ( $0.05 \mathrm{~mol} / 1 \mathrm{NaH}_{2} \mathrm{PO}_{4}, \mathrm{pH} 5.3$, plus $5 \mathrm{~mol} / \mathrm{l}$ $\mathrm{NaOH})$ combined with $57 \%$ solvent B $\left(0.05 \mathrm{~mol} / 1 \mathrm{NaH}_{2} \mathrm{PO}_{4}\right.$ in $75 \%$ methanol $/ \mathrm{H}_{2} \mathrm{O}$ ) filtered with type $\mathrm{FH} 0.5 \mu \mathrm{m}$ Millipore filter and degassed. Glutamine, added after ion exchange chromatography, was used as the internal standard.

Statistical analysis. The results are expressed as means \pm standard deviations. Data were subjected to equality of variance $F$ test, and then to log transformation, if necessary, before oneway analysis of variance. When overall significance $(p<0.05)$ was attained, individual between-group comparisons were made using the Student-Newman-Keuls multiple range test. Statistical significance was defined as a $p$ value of 0.05 or less. When between-group variance differences could not be normalized by log transformation, the data were analysed by the non-parametric Kruskal-Wallis one-way analysis of variance, followed by the Fisher's PLSD test for multiple comparisons.

\section{Results}

The final body weights were lower in diabetic rats than in the control group (Table 1). The initial body weights were similar in control and diabetic groups. No statistically significant difference was found between final body weights in diabetic rats treated with taurine or DL- $\alpha$-lipoic acid and the corresponding untreated groups.

Blood glucose concentration was increased 7.2fold in diabetic rats compared with controls. Blood glucose concentrations in diabetic rats were not affected by taurine or DL- $\alpha$-lipoic acid treatment.

Retinal VEGF concentration was increased 1.8fold in diabetic rats compared with controls (Fig.2). This up regulation was attenuated but not completely prevented by taurine, and was completely prevented by DL- $\alpha$-lipoic acid.

The ribonuclease protection assay showed two major alternatively spliced VEGF mRNA transcripts (Fig. 3A). Retinal VEGF mRNA abundance was reduced 1.4 -fold in diabetic rats compared with controls (Fig. 3B). This reduction was attenuated but not completely prevented by either taurine or DL- $\alpha$-lipoic acid.

MDA plus 4-HA concentration was 1.6-fold higher in the retinae of diabetic rats compared with the control group (Fig. 4). Both antioxidants arrested diabetes-induced lipid peroxidation.

Retinal taurine, GSH, GSSG, DHAA and AA concentrations were similar among control and diabetic rats treated with or without taurine (Table 2 ). Neither glutathione redox state nor ascorbate redox state (expressed as GSSG/GSH and DHAA/AA ratios, respectively) were affected by diabetes or taurine treatment.

Retinal glucose, sorbitol and fructose concentrations were 5.1-fold, 26-fold and 4.75-fold higher in diabetic rats than in the control rats (Fig. 5). Diabetesinduced increase in retinal glucose and sorbitol pathway intermediate concentrations was not affected by dietary taurine supplementation. 


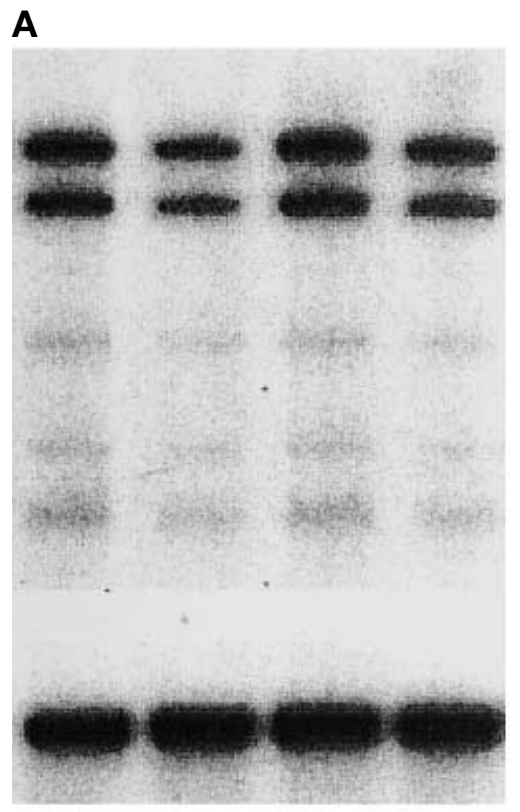

\section{D D $+\mathrm{T}$ D+LA}

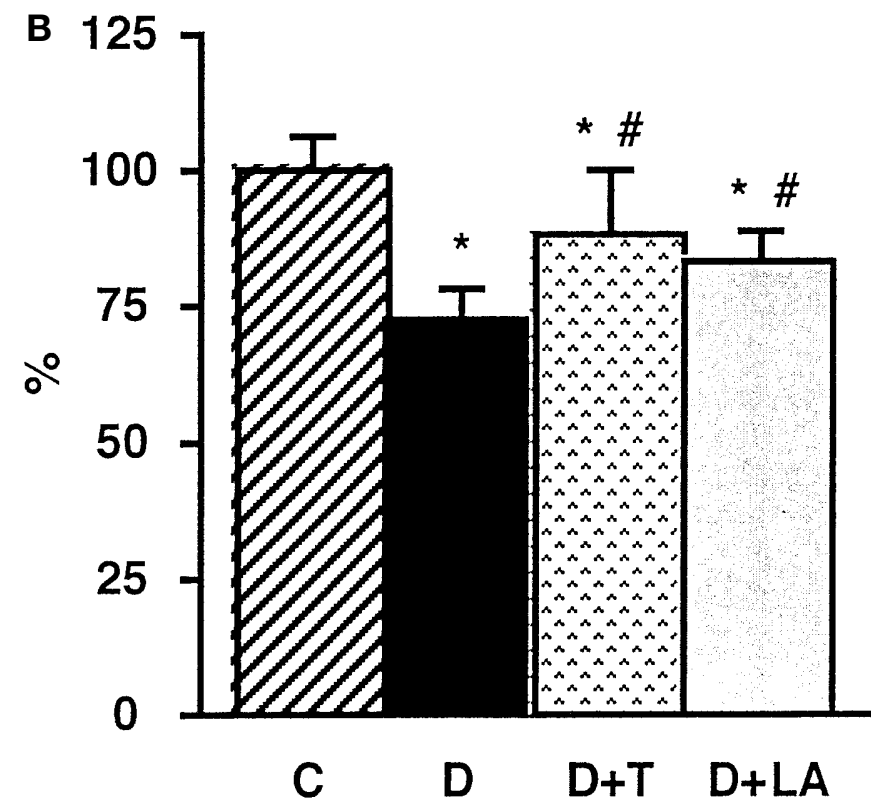

Fig.3A, B. A Representative polyacrylamide gel autoradiograph obtained in the ribonuclease protection assay of VEGF mRNA and $18 \mathrm{~S}$ ribosomal RNA in the retinae of control rats and diabetic rats treated with or without taurine or DL- $\alpha$-lipoic acid. B Retinal VEGF mRNA abundance (mean $\pm \mathrm{SD}, n=8$ ) in the retinae of control and diabetic rats treated with or without taurine or DL- $\alpha$-lipoic acid. Data were normalized to $18 \mathrm{~S}$ ribosomal RNA levels

\section{Discussion}

Measurements of VEGF protein and VEGF mRNA concentrations in ocular tissues of non-diabetic animals and human subjects using in situ hybridization, blotting techniques, and immunohistochemistry resulted in contradictory findings [6, 42-46]. Absent [6,

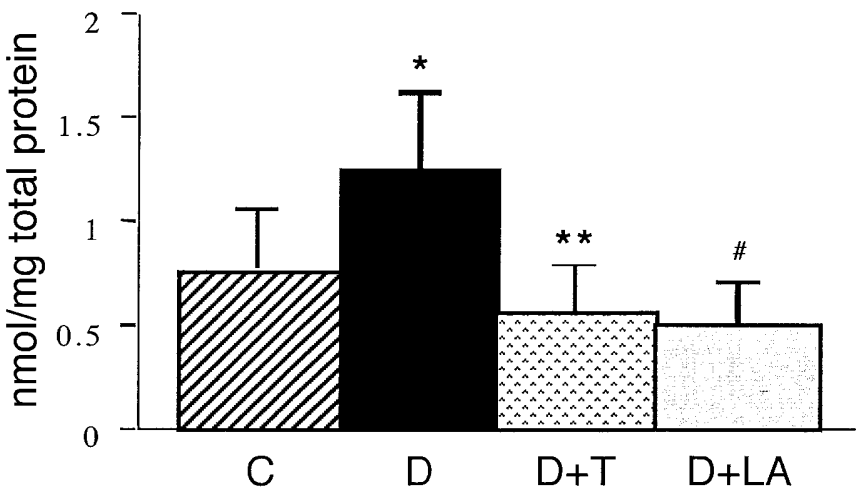

Fig.4. Retinal MDA plus 4-HA concentrations in control and diabetic rats treated with or without taurine or DL- $\alpha$-lipoic acid (mean $\pm \mathrm{SD}, n=8-10$ ). C, controls; $\mathrm{D}$, untreated diabetic group; D + T, diabetic group treated with taurine; D + LA, diabetic group treated with DL- $\alpha$-lipoic acid. *significantly different vs control rats $(p<0.01)$; **significantly different vs untreated diabetic rats $(p<0.01)$

$46,47]$, weak [46, 48] or abundant [49, 50] VEGF immunoreactivity and expression have been reported by different groups. Recent development of highly sensitive ELISAs made possible precise measurements of VEGF protein concentrations in mammalian retinas [51]. Our results (calculated from the standard curve for rat VEGF) agree with those in a study using murine VEGF protein as a standard [51]. Control retinal VEGF protein concentration calculated in our study from murine VEGF standards (Fig.1) was $18.9 \pm 4.68$ i.e.1.6-fold lower than the one calculated from rat VEGF standards. Detection of retinal VEGF protein in non-diabetic animals ([51] and in our study) is consistent with the physiological role for VEGF in retinal vasculogenesis and vascular development [52, 53].

Early diabetes-induced up regulation of retinal VEGF protein, also observed in two other studies in $d b / d b$ mice [35] and streptozotocin-diabetic rats [36], temporally coincides with a decrease in retinal blood flow and impairment of retinal oxygenation $[5,12$, 54] manifested in the decreased free mitochondrial and cytosolic $\mathrm{NAD}^{+} / \mathrm{NADH}$ ratios [39]. The role of oxygen as the major upstream regulatory molecule controlling VEGF production is well established and low oxygen tensions (hypoxia) have a stimulatory effect $[28,29]$. Retinal VEGF up regulation is present as early as six weeks after induction of streptozotocin diabetes and thus precedes manifestations of background diabetic retinopathy. This is consistent with the findings of VEGF immunopositivity in glial cells of the retina and optic nerve in diabetic patients without vascular anatomic abnormalities [55]. The up regulation of retinal VEGF production in short-term diabetes can potentially be responsible for increased expression of the gene coding for intracellular adhesion molecule-1 and extensive leukocyte stasis [56], 


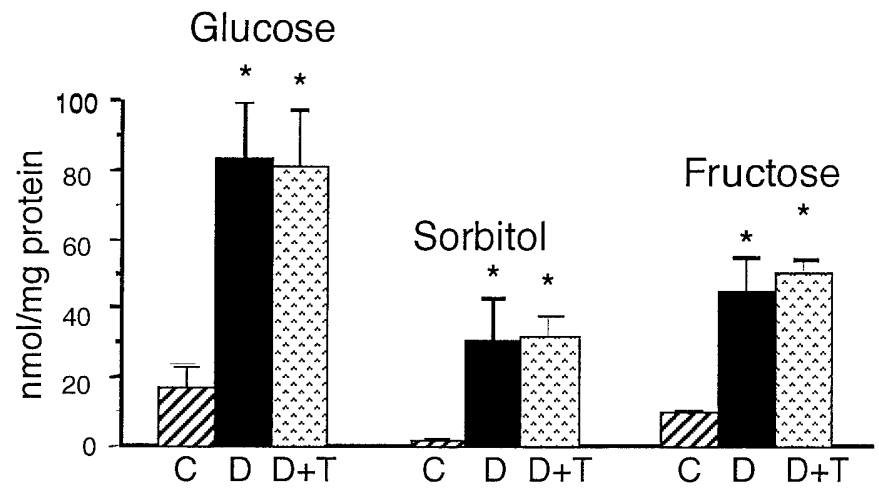

Fig. 5. Retinal sorbitol pathway intermediate concentrations in control and diabetic rats treated with or without taurine (mean $\pm \mathrm{SD}, n=8-10$ ). C, controls; D, untreated diabetic group; $\mathrm{D}+\mathrm{T}$, diabetic group treated with taurine. *significantly different vs control rats $(p<0.01)$

Table 2. Retinal antioxidant concentrations ${ }^{\mathrm{a}}$ and glutathione and ascorbate redox states in control and diabetic rats treated with or without taurine $(n=8-15)$

\begin{tabular}{lccc}
\hline & Control & Diabetic & $\begin{array}{l}\text { Diabetic }+ \\
\text { Taurine }\end{array}$ \\
\hline Taurine & $244 \pm 42$ & $209 \pm 42$ & $245 \pm 68$ \\
GSH & $16.6 \pm 5.9$ & $15.3 \pm 3.1$ & $14.3 \pm 3.3$ \\
GSSG & $0.306 \pm 0.045$ & $0.318 \pm 0.023$ & $0.327 \pm 0.018$ \\
GSSG/GSH & $0.020 \pm 0.005$ & $0.021 \pm 0.004$ & $0.024 \pm 0.04$ \\
Total AA & $16.5 \pm 4.5$ & $18.9 \pm 3.1$ & $20.0 \pm 9.4$ \\
AA & $15.1 \pm 4.6$ & $16.9 \pm 3.1$ & $7.9 \pm 8.5$ \\
DHAA & $2.06 \pm 0.69$ & $2.12 \pm 0.48$ & $2.1 \pm 1.1$ \\
DHAA/AA & $0.129 \pm 0.020$ & $0.130 \pm 0.024$ & $0.115 \pm 0.027$ \\
\hline
\end{tabular}

${ }^{a}$ Concentrations of taurine, GSH, GSSG, total AA, AA and DHAA are expressed in $\mathrm{nmol} / \mathrm{mg}$ total protein

as well as decreased occludin expression with subsequent weakening of interendothelial tight junctions [24] and nonendothelial changes [56] leading to increased vascular permeability. Furthermore, VEGF activates endothelial cell p44/42 mitogen-activated protein (MAP) kinase [57] and thus is probably involved in p44/p42 MAP kinase-dependent [58] overexpression of endothelin-1 present early in the course of diabetes [54].

Of interest, VEGF mRNA concentration was reduced rather than increased in short-term diabetes. Although most of the studies describe unidirectional changes of VEGF mRNA and VEGF protein concentrations in response to different stimuli (including strong oxidative insult in cell culture experiments [21, 22]) and in pathological states involving angiogenesis, some reports indicate the discordance between VEGF expression at mRNA and protein level. In particular, stimulation of VEGF synthesis at low $\mathrm{O}_{2}$ tension in human proximal tubular cells was detectable at the protein level only [59]. Stimulation of platelets with thrombin and of polymorphonuclear neutrophils with the activator of protein kinase $\mathrm{C}$ phorbol 12-myristate 13-acetate induced a time-dependent release of VEGF, peaking after 30 and $60 \mathrm{~min}$, respectively, i.e. within the time frame insufficient to change VEGF gene expression [60]. Recently, it has been reported that phosphorylation of the initiation factor (eIF) 4E known to play an important part in the translational regulation of VEGF [61], correlates with the activation of protein synthesis and occurs via both protein kinase C-dependent and protein kinase $\mathrm{C}$-independent signalling pathways [62]. Thus, it is plausible that post-transcriptional up regulation of retinal VEGF protein in early diabetes is mediated via activation of protein kinase $\mathrm{C}$ $[5,7]$. Correspondingly, down regulation of retinal VEGF protein concentrations by taurine and DL- $\alpha$-lipoic acid could be from the inhibitory effect of antioxidants on protein kinase $\mathrm{C}$ activity [63]. Apparently, control of VEGF protein expression in tissue-sites for diabetic complications is complex and different components could predominate in short-term and long-term diabetes [64].

Our data on two diverse antioxidants provides evidence of a causal relation between diabetes-induced retinal oxidative stress and VEGF protein formation in early diabetes. The role of oxidative stress in excessive retinal VEGF production in diabetes of longer duration is supported by strong positive correlations between lipid peroxidation product and VEGF protein concentrations in the vitreous of patients with proliferative diabetic retinopathy [27], and between retinal hydrogen peroxide and VEGF concentrations in the BBZ/Wor diabetic rats examined at 4.5 to 18.0 months of diabetes [14]. In vitro studies and observations in animal models suggest that oxidative stress contributes to diabetes-induced retinal VEGF production through both hypoxia-mediated and hypoxia-independent mechanisms.

Early increase in lipid peroxidation in the retina, unlike other tissues of streptozotocin-diabetic rats $[9-11,40,65]$, occurs in the absence of glutathione[66] and in our studies, taurine and ascorbate depletion or changes in the glutathione and ascorbate redox states. Despite total arrest of diabetes-induced retinal lipid peroxidation by both antioxidants, DL- $\alpha-$ lipoic acid completely prevented, whereas taurine only attenuated, VEGF up regulation. There is no doubt that the potent free radical scavenger and metal chelator DL- $\alpha$-lipoic acid [67] counteracts oxidative stress far more effectively than taurine. In addition, in biological tissues DL- $\alpha$-lipoic acid is reduced to dihydrolipoate, which combines free radical (hydroxyl, superoxide, peroxyl, singlet oxygen) scavenging and metal chelating properties with the ability to regenerate concentrations of non-enzymatic and enzymatic antioxidants [34, 67, 68]. Our previous study suggests that the antioxidant effects of DL- $\alpha$-lipoic acid in the retina of streptozotocin-diabetic rats are caused by free radical scavenging and metal chelating proper- 
ties rather than to changes in GSH and GSSG concentrations and the glutathione redox state [34].

The mechanism(s) of antioxidant activity of taurine is poorly understood although the ability of taurine to decrease diabetes-induced lipid peroxidation has been shown in several studies $[40,69,70]$. It has been reported [71, 72] that taurine decreases luminol-dependent chemiluminescence elicited by chemically generated hydroxyl radicals and $t$-butyl hydroperoxide whereas others [73] indicate that hypotaurine, a taurine precursor, rather than taurine itself, has antioxidative properties against ROS. Both taurine and hypotaurine scavenge hypochlorite [73], and the retina contains the hypochlorite-producing enzyme, myeloperoxidase [74]. In addition, taurine decreases superoxide anion abundance by an unknown mechanism [75] and accelerates catabolism of norepinephrine [76] which can autoxidize and thus contribute to ROS generation. Our findings show that the antioxidant effects of taurine in the retina are not mediated through the glutathione and ascorbate systems of antioxidative defence. In addition, we could not detect any substantial increase in retinal taurine concentration in diabetic rats which were fed a taurine-supplemented diet. The retina has a remarkable capacity to maintain taurine concentration $[77,78]$, and any access of retinal taurine is probably rapidly removed after the cessation of food intake.

The relation between the sorbitol pathway activity, oxidative stress and VEGF production deserves specific consideration because both structurally diverse AR inhibitors [3, 6, 79-81] and less extensively studied antioxidants $[15,82]$ prevent vascular abnormalities characteristic of diabetic retinopathy. Recently, it was hypothesized that oxidative stress is a cause of AR activation and sorbitol pathway intermediate accumulation in tissue-sites for diabetic complications [83]. In our study, however, retinal glucose, sorbitol and fructose concentrations were similarly increased in diabetic rats fed regular and taurine-supplemented diets. Furthermore, DL- $\alpha$-lipoic acid which is known to increase glucose transport $[84,85]$ by facilitating translocation of glucose transporters towards the plasma membrane [84], exacerbates diabetes-induced retinal sorbitol pathway intermediate accumulation [39]. The absence of any suppression of the sorbitol pathway activity by two diverse antioxidants, both of which arrest lipid peroxidation and neutralize superoxide anion radicals $[67,75]$, suggests that oxidative stress is not likely to be the cause of retinal sorbitol pathway metabolite accumulation in diabetes. The arrest of VEGF production by DL- $\alpha$-lipoic acid and taurine, both of which counteract oxidative stress but do not suppress the sorbitol pathway hyperactivity, does not contradict an important role for AR in VEGF up regulation. Our findings are consistent with downstream localization of diabetes-associated oxidative stress consequent to increased AR activity [11, 32, 86-89] which, therefore, renders VEGF up regulation preventable by both AR inhibitors [6] and antioxidants.

In conclusion, oxidative stress causes increased VEGF production in the retina in early diabetes. This up regulation is detectable at the protein, but not mRNA level. The findings support the rationale for evaluating potent antioxidants, such as DL- $\alpha$-lipoic acid, dietary antioxidant mixtures and antioxidantcontaining combination therapies to prevent the onset or progression of diabetic retinopathy.

Acknowledgements. This study was supported by the Juvenile Diabetes Research Foundation Center for the Study of Complications of Diabetes Grant 4-200-421 (I. G. Obrosova), the National Institutes of Health Grant RO1-DK52391 (M.J.Stevens) and Veterans Administration Career Development Award (M. J.Stevens).

\section{References}

1. Anonymous (2000) Retinopathy and nephropathy in patients with type 1 diabetes four years after a trial of intensive therapy. The Diabetes Control and Complications Trial/Epidemiology of Diabetes Interventions and Complications Research Group. N Engl J Med 342: 381-389

2. Anonymous (1998) Intensive blood-glucose control with sulphonylureas or insulin compared with conventional treatment and risk of complications in patients with type 2 diabetes (UKPDS 33). UK Prospective Diabetes Study (UKPDS) Group. Lancet 352: 837-853

3. Kador PF (1988) The role for aldose reductase in the development of diabetic complications. Med Res Rev 8: 325-352

4. Vlassara H (1997) Recent progress in advanced glycation end products and diabetic complications. Diabetes 46 [Suppl 2]:S19-S25

5. Koya D, King GL (1998) Protein kinase C activation and the development of diabetic complications. Diabetes 47: 859-866

6. Frank RN, Amin R, Kennedy A, Hohman TC (1997) An aldose reductase inhibitor and aminoguanidine prevent vascular endothelial growth factor expression in rats with long-term galactosemia. Arch Ophthalmol 115: 1036-1047

7. Aiello LP, Bursell SE, Clermont A et al (1997) Vascular endothelial growth factor-induced retinal permeability is mediated by protein kinase $\mathrm{C}$ in vivo and suppressed by an orally effective beta-isoform-selective inhibitor. Diabetes 46: $1473-1480$

8. Hammes HP, Brownlee M, Lin J, Schleicher E, Bretzel RG (1999) Diabetic retinopathy risk correlates with intracellular concentrations of the glycoxidation product Nepsilon-(carboxymethyl) lysine independently of glycohaemoglobin concentrations. Diabetologia 42: 603-607

9. Obrosova IG, Fathallah L, Lang HJ (1999) Interaction between osmotic and oxidative stress in diabetic precataractous lens. Studies with a sorbitol dehydrogenase inhibitor. Biochem Pharmacol 58: 1945-1954

10. Low PA, Nickander KK, Tritschler HJ (1997) The roles of oxidative stress and antioxidant treatment in experimental diabetic neuropathy. Diabetes 46 [Suppl 2]: S38-S42

11. Obrosova IG, Greene DA, Lang HJ (2000) Antioxidative Defense in Diabetic Peripheral Nerve: Effects of DL- $\alpha$-Lipoic Acid, Sorbitol Dehydrogenase Inhibitor and Aldose Reductase Inhibitor. In: Packer L, Rosen P, Tritschler HJ, King GL, Azzi A (eds) Antioxidants in Diabetes Management, Marcel Dekker, New York, pp 93-110

12. Bursell SE, Clermont AC, Aiello LP et al. (1999). High-dose vitamin $\mathrm{E}$ supplementation normalizes retinal blood flow and 
creatinine clearance in patients with type 1 diabetes. Diabetes Care 22: $1245-1251$

13. Ellis EA, Grant MB, Murray FT et al. (1998) Increased NADH oxidase activity in the retina of the BBZ/Wor diabetic rat. Free Radic Biol Med 24: 111-120

14. Ellis EA, Guberski DL, Somogyi-Mann M, Grant MB (2000) Increased $\mathrm{H}_{2} \mathrm{O}_{2}$, vascular endothelial growth factor and receptors in the retina of the BBZ/Wor diabetic rat. Free Radic Biol Med 28: 91-101

15. Hammes HP, Bartmann A, Engel L, Wulfroth P (1997) Antioxidant treatment of experimental diabetic retinopathy in rats with nicanartine. Diabetologia 40: 629-634

16. Kern TS, Tang J, Mizutani M et al. (2000) Response of capillary cell death to aminoguanidine predicts the development of retinopathy: comparison of diabetes and galactosemia. Invest Ophthalmol Vis Sci 41: 3972-3978

17. Shojaee N, Patton WF, Hechtman HB, Shepro D (1999) Myosin translocation in retinal pericytes during free-radical induced apoptosis. J Cell Biochem 75: 118-129

18. Walisser JA, Thies RL (1999) Poly(ADP-ribose) polymerase inhibition in oxidant-stressed endothelial cells prevents oncosis and permits caspase activation and apoptosis. Exp Cell Res 251: 401-413

19. Soldatenkov VA, Smulson M (2000) Poly(ADP-ribose)polymerase in DNA damage-response pathway: implications for radiation oncology. Int J Cancer 90: 59-67

20. Oka M, Hirouchi M, Itoh Y, Ukai Y (2000) Involvement of peroxynitrite and hydroxyradical generated from nitric oxide in hypoxia/reoxygenation injury in rat cerebrocortical slices. Neuropsychopharmacology 39: 1319-1330

21. Kuroki M, Voest E, Amano S et al. (1996). Reactive Oxygen Intermediates Increase Vascular Endothelial Growth Factor Expression In Vitro and In Vivo. J Clin Invest 98: 1667-1675

22. Lu M, Kuroki M, Amano S et al. (1998) Advanced glycation end products increase retinal vascular endothelial growth factor expression. J Clin Invest 101: 1219-1224

23. Higgins GT, Wang JH, Cleary PE, Redmond HP (2000) Taurine, $\alpha$-tocopherol and ascorbate attenuate in vitro vascular endothelial growth factor (VEGF) release from retinal pigment epithelial (RPE cells). Ophthalmic Res 32 [Suppl 2] A47 Abstract

24. Antonetti DA, Barber AJ, Hollinger LA, Wolpert EB, Gardner TW (1999) Vascular endothelial growth factor induces rapid phosphorylation of tight jucntion proteins occludin and zonula occluden 1 . A potential mechanism for vascular permeability in diabetic retinopathy and tumors. J Biol Chem 274: 23463-23467

25. Frank RN, Amin RH, Eliott D, Puklin JE, Abrams GW (1996) Basic fibroblast growth factor and vascular endothelial growth factor are present in epiretinal and choroidal neovascular membranes. Am J Ophthalmol 122: 393-403

26. Miller JW, Adamis AP, Aiello LP (1997) Vascular endothelial growth factor in ocular neovascularization and proliferative diabetic retinopathy. Diabetes-Metab Rev 13: 37-50

27. Augustin AJ, Dick HB, Grus F (2000) Oxidative metabolites and VEGF in proliferative diabetic retinopathy. Exp Eye Res 71 [Suppl 1] A139 Abstract

28. Shweiki D, Itin A, Soffer D, Keshet E (1992) Vascular endothelial growth factor induced by hypoxia may mediate hypoxia-initiated angiogenesis. Nature 359: 843-845

29. Minchenko A, Bauer T, Salceda S, Caro J (1994) Hypoxic stimulation of vascular endothelial growth factor expression in vitro and in vivo. Lab Invest 71: 374-379

30. Brooks SE, Gu X, Kaufmann PM, Marcus DM, Caldwell RB (1998) Modulation of VEGF production by $\mathrm{pH}$ and glucose in retinal Muller cells. Curr Eye Res 17: 875-882

31. Shweiki D, Neeman M, Irin A, Keshet E (1995) Induction of vascular endothelial growth factor expression by hypoxia and by glucose deficiency in multicell spheroids: Implications by tumor angiogenesis. Proc Natl Acad Sci USA 92: 768-772

32. Obrosova IG, Fathallah L (2000) Evaluation of an aldose reductase inhibitor on lens metabolism, ATPases and antioxida- tive defense in streptozotocin-diabetic rats: an intervention study. Diabetologia 43: 1048-1055

33. Chou SM, Han CY, Wang HS, Vlassara H, Bucala R (1999) A receptor for advanced glycosylation endproducts (AGEs) is colocalized with neurofilament-bound AGEs and SOD1 in motoneurons of ALS: immunohistochemical study. J Neurol Sci 169: 87-92

34. Obrosova IG, Fathallah L, Greene DA (2000) Early changes in lipid peroxidation and antioxidative defense in diabetic rat retina: effect of DL- $\alpha \alpha$-lipoic acid. Eur J Pharmacol 398: 139-146

35. Amin RH, Frank RN, Heilig C (1999) Short term diabetic mice upregulate vascular endothelial growth factor (VEGF) protein in retinal neurons. Invest Ophthalmol Vis Sci 40 A370 Abstract

36. Tsujikawa A, Qin W, Xu Q et al. (2000) Inhibition of VEGF suppresses early diabetic retinal leukostasis. Invest Ophthalmol Vis Sci 41 A651 Abstract

37. Block F, Schwartz M (1997) Effects of antioxidants on ischemic retinal dysfunction. Exp Eye Res 64: 559-564

38. Lepore D, Di Leo MA, Cercone S et al. (2000) Oxidative stress in STZ-induced diabetic rats: preventive effects of taurine. Invest Ophthalmol Vis Sci 41 A407 Abstract

39. Obrosova IG, Stevens MJ, Lang HJ (2001) Diabetes-Induced Changes in Retinal NAD-Redox Status. Pharmacological Modulation and Implications for Pathogenesis of Diabetic Retinopathy. Pharmacology 62: 172-180

40. Chomczynski P, Sacchi N (1987) Single-step method of RNA isolation by acid guanidium thiocyanate-phenol-chlorophorm extraction. Anal Biochem 162: 156-159

41. Minchenko A, Caro J (2000) Regulation of endothelin-1 gene expression in human microvascular endothelial cells by hypoxia and cobalt: role of hypoxia responsive element. Mol Cell Biochem 208: 53-62

42. Claffey KP, Wilkinson WO, Spiegelman BM (1992) Vascular endothelial growth factor. Regulation by cell differentiation and activated messenger pathways. J Biol Chem 267: $16317-16322$

43. Torczynski RM, Bollon AP, Fuke M (1983) The complete nucleotide sequence of the rat $18 \mathrm{~S}$ ribosomal RNA gene and comparison with the respective yeast and froggenes. Nucleic Acid Res 11: 4879-4890

44. Obrosova IG, Stevens MJ (1999) Effect of dietary taurine supplementation on GSH and NAD(P)-redox status, lipid peroxidation, and energy metabolism in diabetic precataractous lens. Invest Ophthalmol Vis Sci 40: 680-688

45. Jones BN, Paabo S, Stein S (1981) Amino acid analysis and enzymatic sequence determination of peptides by an improved O-phthaldialdehyde precolumn labeling procedure. J Liq Chromat 4: 565-586

46. Lutty GA, McLeod DS, Merges C, Diggs A, Plouet J (1996) Localization of vascular endothelial growth factor in human retina and choroid. Arch Ophthalmol 114: 971-977

47. Hammes HP, Lin J, Bretzel RG, Brownlee M, Breier G (1998) $\mathrm{Up}$ regulation of the vascular endothelial growth factor/vascular endothelial growth factor receptor system in experimental background diabetic retinopathy of the rat. Diabetes 47: 401-406

48. Murata T, Nakagawa K, Khalil A, Ishibashi T, Inomata $H$, Sueishi K (1996) The relation between expression of vascular endothelial growth factor and breakdown of the blood-retinal barrier in diabetic rat retinas. Lab Invest 74: 819-825

49. Gilbert RE, Vranes D, Berka JL et al. (1998) Vascular endothelial growth factor and its receptors in control and diabetic rat eyes. Lab Invest 78: 1017-1027

50. Gerhardinger C, Brown LF, Roy S, Mizutani M, Zucker CL, Lorenzi M (1998) Expression of vascular endothelial growth factor in the human retina and in nonproliferative diabetic retinopathy. Am J Pathol 152: 1453-1462

51. Kim I, Ryan AM, Rohan R et al. (1999) Constitutive expression of VEGF, VEGFR-1, and VEGFR-2 in normal eyes. Invest Ophthalmol Vis Sci 40: 2115-2121 
52. Alon T, Hemo I, Itin A, Pe'er J, Stone J, Keshet E (1995) Vascular endothelial growth factor acts as a survival factor for newly formed retinal vessels and has implications for retinopathy of prematurity. Nat Med 1: 1024-1028

53. Murata T, Nakagawa K, Khalil A, Ishibashi T, Inomata $H$, Sueishi K (1996) The temporal and spatial vascular endothelial growth factor expression in retinal vasculogenesis of rat neonates. Lab Invest 74: 68-77

54. Deng D, Evans T, Mukherjee K, Downey D, Chakrabarti S (1999) Diabetes-induced vascular dysfunction in the retina: role of endothelins. Diabetologia 42: 1228-1234

55. Amin RH, Frank RN, Kenedy A, Eliott D, Puklin JE, Abrams GW (1997) Vascular endothelial growth factor is present in glial cells of the retina and optic nerve of human subjects with nonproliferative diabetic retinopathy. Invest Ophthalmol Vis Sci 38: 36-47

56. Miyamoto K, Khosrof S, Bursell SE et al. (2000). Vascular endothelial growth factor (VEGF)-induced retinal vascular permeability is mediated by intercellular adhesion molecule- 1 (ICAM-1). Am J Pathol 156: 1733-1739

57. Murata M, Kador PF, Sato S (2000) Vascular endothelial growth factor enhances the expression of receptors and activates mitogen-activated protein (MAP) kinase of dog retinal capillary endothelial cells. J Ocul Pharmacol Ther 16: 383-391

58. Park JY, Takahara N, Gabriele A et al. (2000) Induction of endothelin-1 expression by glucose: an effect of protein kinase $\mathrm{C}$ activation. Diabetes 49: 1239-1248

59. El Awad B, Kreft B, Wolber EM et al. (2000) Hypoxia and interleukin-1beta stimulate vascular endothelial growth factor production in human proximal tubular cells. Kidney Int 58: $43-50$

60. Koehne P, Willam C, Strauss E, Schindler R, Eckardt KU, Buhrer C (2000) Lack of hypoxic stimulation of VEGF secretion from neutrophils and platelets. Am J Physiol 279: H817-H824

61. Crew JP, Fuggle S, Bicknell R, Cranston DW, de Benedetti A, Harris AL (2000) Eukaryotic initiation factor-4E in superficial and muscle invasive bladder cancer and its correlation with vascular endothelial growth factor expression and tumour progression. Br J Cancer 82: 161-166

62. Morley SJ (1997) Signalling through either the p38 or ERK mitogen-activated protein (MAP) kinase pathway is obligatory for phorbol ester and T cell receptor complex (TCR-CD3)stimulated phosphorylation of initiation factor (elF)4E in Jurkat T cells. FEBS Lett 418: 327-332

63. Kowluru RA, Kern TS (2001) Antioxidants inhibit the development of retinopathy in diabetic rats and in galactose-fed rats. Invest Ophthalmol Vis Sci 42: S208 Abstract

64. Gilbert RE, Kelly DJ, Cox AJ et al. (2000) Angiotensin converting enzyme inhibition reduces retinal overexpression of vascular endothelial growth factor and hyperpermeability in experimental diabetes. Diabetologia 43: 1360-1367

65. Nagamatsu M, Nickander KK, Schmelzer JD et al. (1995) Lipoic acid improves nerve blood flow, reduces oxidative stress, and improves distal nerve conduction in experimental diabetic neuropathy. Diabetes Care18: 1160-1167

66. Agardh CD, Agardh E, Qian Y, Hultberg B (1998) Glutathione levels are reduced in diabetic rat retina but are not influenced by ischemia followed by recirculation. Metabolism 47: 269-272

67. Packer L, Witt EH, Tritschler HJ (1995) $\alpha$-Lipoic acid as a biological antioxidant. Free Radic Biol Med 19: 227-250

68. Maitra I, Serbinova E, Trischler H, Packer L (1995) $\alpha$-lipoic acid prevents buthionine-sulfoximine-induced cataract formation in newborn rats. Free Radic Biol Med 18: 823-829

69. Trachtman H, Futterweit S, Maesaka J et al. (1995) Taurine ameliorates chronic streptozocin-induced diabetic nephropathy in rats. Am J Physiol 269: F429-F438
70. Lim E, Park S, Kim H (1998) Effect of taurine supplementation on the lipid peroxide formation and the activities of glutathione-related enzymes in the liver and islet of type I and II diabetic model mice. Adv Exp Med Biol 442: 99-103

71. Raschke P, Massoudy P, Becker BF (1995) Taurine protects the heart from neutrophil-induced reperfusion injury. Free Radic Biol Med 19: 461-471

72. Gumuslu S, Yucel G, Aydin M, Yesilkaya A, Demir AY, Aksu TA (1996) The role of antioxidants in the prevention of t-butyl hydroperoxide-induced chemiluminescence. Int J Clin Lab Res 26: 119-123

73. Aruoma OI, Halliwell B, Hoey BM, Butler J (1988) The antioxidant action of taurine, hypotaurine and their metabolic precursors. Biochem J 256: 251-255

74. Ambati J, Gragoudas ES, Miller JW et al. (2000) Transscleral delivery of bioactive protein to the choroid and retina. Invest Ophthalmol Vis Sci 41: 1186-1191

75. Kilic F, Bhardwaj R, Caufeild J, Trevithick JR (1999) Modelling cortical cataractogenesis 22: is in vitro reduction of damage in model diabetic rat cataract by taurine due to its antioxidant activity? Exp Eye Res 69: 291-300

76. Chabine R, Hanna J, Abou Khalil K et al. Taurine and myocardial noradrenaline. Arzneimittel forschung 44: 126-128

77. Sturman JA, Bassin DK, Hayes KC, Gaull GE (1978) Taurine deficiency in the kitten: exchange and turnover of [35S]taurine in brain, retina, and other tissues. J Nutr 108: 1462-1476

78. Vilchis C, Salceda R (1996) Effect of diabetes on levels and uptake of putative amino acid neurotransmitters in rat retina and retinal pigment epithelium. Neurochem Res 21: 1167-1171

79. Kojima K, Matsubara H, Harada T et al. (1985) Effects of aldose reductase inhibitor on retinal microangiopathy in streptozotocin-diabetic rats. Jpn J Ophthalmol. 29: 99-109

80. Robinson WG Jr, Laver NM, Jacot JL et al. (1996) Diabeticlike retinopathy ameliorated with the aldose reductase inhibitor WAY-121,509. Invest Ophthalmol Vis Sci 37: 1149-1156

81. Neuenschwander H, Takahashi Y, Kador PF (1997) Dose-dependent reduction of retinal vessel changes associated with diabetic retinopathy in galactose-fed dogs by the aldose reductase inhibitor M79175. J Ocul Pharmacol Ther 13: 517-528

82. Ansari NH, Zhang W, Fulep E (1998) Prevention of pericyte loss by trolox in diabetic rat retina. $\mathrm{J}$ Toxicol Environ Health 54: 467-475

83. Nishikawa T, Edelstein D, Brownlee M (2000) The missing link: a single unifying mechanism for diabetic complications. Kidney Int 58[Suppl 77]:S26-S30

84. Bashan N, Burdett E, Gum A (1993) Effect of thioctic acid on glucose transport. In: Gries FA, Wessel E (eds) The Role of Anti-oxidants in Diabetes Mellitus - Oxygen Radicals and Antioxidants in Diabetes, Verlag-Gruppe, Frankfurt am Main, pp 221-226

85. Kishi Y, Schmelzer JD, Yao JK et al. (1999) Alpha-lipoic acid: effect on glucose uptake, sorbitol pathway, and energy metabolism in experimental diabetic neuropathy. Diabetes 48: 2045-2051

86. Lou MF, Dickerson JE Jr, Garadi R, York BM Jr (1988) Glutathione depletion in the lens of galactosemic and diabetic rats. Exp Eye Res 46: 517-530

87. Lee AYW, Chung SSM (1999) Contribution of polyol pathway to oxidative stress in diabetic cataract. FASEB J 13 23-30

88. Cameron NE, Cotter MA, Jack AM, Basso MD, Hohman TC (1999) Protein kinase C effects on nerve function, perfusion, $\mathrm{Na}(+), \mathrm{K}(+)$-ATPase activity and glutathione content in diabetic rats. Diabetologia 42: 1120-1130 